\title{
Inventory and conservation of endangered, endemic and economically important flora of Hamiguitan Range, southern Philippines
}

\author{
V.B. Amoroso ${ }^{1}$, L.D. Obsioma1 ${ }^{1}$, J.B. Arlalejo², R.A. Aspiras ${ }^{1}$, D.P. Capili", \\ J.J.A. Polizon ${ }^{1}$, E.B. Sumile ${ }^{2}$
}

Key words

assessment

diversity

Philippines protected area

vegetation types

\begin{abstract}
This research was conducted to inventory and assess the flora of Mt Hamiguitan. Field reconnaissance and transect walk showed four vegetation types, namely: dipterocarp, montane, typical mossy and mossy-pygmy forests. Inventory of plants showed a total of 878 species, 342 genera and 136 families. Of these, 698 were angiosperms, 25 gymnosperms, 41 ferns and 14 fern allies. Assessment of conservation status revealed 163 endemic, 34 threatened, 33 rare and 204 economically important species. Noteworthy findings include 8 species as new record in Mindanao and one species as new record in the Philippines. Density of threatened species is highest in the dipterocarp forest and decreases at higher elevation. Species richness was highest in the montane forest and lowest in typical mossy forest. Endemism increases from the dipterocarp to the montane forest but is lower in the mossy forest. The results are compared with data from other areas.
\end{abstract}

Published on 30 October 2009

\section{INTRODUCTION}

Mount Hamiguitan Range Wildlife Sanctuary in Davao Oriental is a protected area covering 6834 ha located between $6^{\circ} 46^{\prime} 6^{\circ} 40^{\prime} 01^{\prime \prime}$ to $6^{\circ} 46^{\prime} 60^{\prime \prime} \mathrm{N}$ and $126^{\circ} 09^{\prime} 02^{\prime \prime}$ to $126^{\circ} 13^{\prime} 01^{\prime \prime} \mathrm{E}$. The mountain is known for its unique characteristics and the largest pygmy 'bonsai forest' in the country. This forest type has a substrate predominated by ultrabasic rocks. The rock weathers leaving the soil with an unusually high concentration of iron and magnesium causing it to be unproductive for agricultural activities. Only a specialized group of plants grow on this type of forest which is often low, heath-like shrubs. Nepenthes alata Blanco, a facultative ultrabasic, as well as obligate ultrabasic species of Nepenthes (Nepenthaceae) were found to be numerous in the area. Other ultrabasic indicator species such as Scaevola micrantha (Krause) C.Presl (Goodeniaceae), Scaevola sp., Suregada glomerulata (Blume) Baill. (Euphorbiaceae) and Ochrosia glomerata (Blume) F.Muell. (Apocynaceae) were also found thriving in the vegetation.

The unique biodiversity resources in Mt Hamiguitan Range have not been spared from destruction such as timber poaching, illegal logging and overharvesting of forest products and resources. This will be aggravated because of the forthcoming mining activities. As a result, elements of the important flora and fauna may be lost before they are recorded, studied and conserved.

This research aimed to inventory and assess the flora in Mt Hamiguitan Range Wildlife Sanctuary and its surroundings. Specifically, it aimed to identify and describe the vegetation types; determine the diversity and species importance values (SIV); assess the conservation status of the species whether endemic, endangered, rare and economically important; and, determine the threatened and endemic species distributions and habitats for conservation.

\footnotetext{
1 Central Mindanao University, Musuan, Bukidnon.

2 Davao Oriental State College of Science and Technology, Davao Oriental.
}

\section{METHODOLOGY}

\section{Vegetation types}

Field reconnaissance and transect walks were conducted to identify and describe the vegetation types occurring in $\mathrm{Mt}$ Hamiguitan Range. On basis of species composition, altitude and other ecological indicators, we identified four vegetation types as a basis for further analysis. In addition, the term agroecosystem is used to refer to the cultivated areas around the villages.

\section{Diversity indices}

To determine species richness, transect walks were undertaken and sampling plots were established with the assistance of Bantay Gubat. Per vegetation type a 2-ha transect walk was conducted with a local expert and transect belts were established.

A total of thirty-two $20 \times 20 \mathrm{~m}$ sampling plots were established in all vegetation types, each type with 6 sampling plots except for the dipterocarp forest with 14 plots. Within these plots, a $5 \times 5 \mathrm{~m}$ subplot was laid out to determine the species richness for shrubs, vines and herbs. We assessed species diversity by using the Shannon index of general diversity $(\mathrm{H})$ :

$$
\mathrm{H}=-\Sigma \mathrm{ndbh} / \mathrm{Ndbh} \log \mathrm{ndbh} / \mathrm{Ndbh}
$$

where

ndbh $=$ total diam at breast height of individual tree species $\mathrm{Ndbh}=$ total diam at breast height of all tree species

The Species Importance Value (SIV) was computed using the formula of Brower \& Zar (1977):

$\mathrm{SIV}$ or $\mathrm{ni}=\mathrm{RD}+\mathrm{RF}+\mathrm{Rdom}$

where

$$
\begin{aligned}
& \mathrm{RD}=\text { Relative Density } \\
& \mathrm{RF}=\text { Relative Frequency } \\
& \text { Rdom }=\text { Relative Dominance }
\end{aligned}
$$


Table 1 Total number of families, genera and species of flora in Mt Hamiguitan Range.

\begin{tabular}{lrrr}
\hline Plant group & Families & Genera & Species \\
\hline Angiosperms & 101 & 273 & 698 \\
Gymnosperms & 4 & 6 & 25 \\
Ferns & 28 & 59 & 141 \\
Fern allies & 3 & 4 & 14 \\
Total & 136 & 342 & 878 \\
\hline
\end{tabular}

\section{Identification of collected specimens}

The collected plants were identified using available floras and monographs (Merrill 1926, Ashton 1982, Rödl-Linder 1987, Brummitt 1992, Madulid 1995, Amoroso et al. 1996, Barcelona et al. 1996, Huang 1996, 1997, Hovenkamp et al.1998, Nooteboom 1998, Rojo 1999, De Wilde 2000, Jebb \& Cheek 2001, Cootes 2001, Berg \& Corner 2005, Middleton 2007). Mr. Leonardo L. Co (Conservation International) and Dr. Paul Keßler (Nationaal Herbarium Nederland, Leiden branch) confirmed the identification of some species.

\section{Assessment of conservation status}

We assessed conservation status of the species in Mt Hamiguitan Range and their status as endemic, rare or economically important, using the data from Merrill (1923-1926), Zamora \& Co (1986), Madulid (1995), Tan et al. (1996), Rojo (1999) and Flora Malesiana Series (1995-2007) and the DENR Administrative Order (2007).

\section{Identification of threatened and endemic species and habitats for conservation}

The type of vegetation, altitude, and location of endemic, endangered, rare and economically important species and their habitats were recorded whenever they were encountered. Transect diagrams were prepared to identify the location and distribution of the threatened and endemic species. The result of this method will be the basis for in situ conservation of the threatened habitats and species.

\section{RESULTS}

\section{Vegetation types}

We identified four vegetation types: dipterocarp forest, montane forest, typical mossy forest and mossy-pygmy forest.

The dipterocarp forest is situated around $6^{\circ} 43^{\prime} 30^{\prime \prime} \mathrm{N}$ and $126^{\circ} 09^{\prime} 01 " \mathrm{E}$, with altitude ranging from 420-920 m. Shorea spp. (Dipterocarpaceae) and vines (Smilax spp., Smilacaceae) dominate the forest. The height of trees ranges from $5-30 \mathrm{~m}$.

The montane forest is situated around $6^{\circ} 44^{\prime} 08^{\prime \prime} \mathrm{N}$ and $126^{\circ} 20^{\prime} 08^{\prime \prime} \mathrm{E}$, with altitude ranging from 920-1160 m. Agathis philippinensis Warb.(Araucariaceae), various species of Nepenthes sp. (Nepenthaceae) and epiphytes characterize this type. The height of trees ranges from 5-25 m, decreasing as the altitude increases.

The typical mossy forest is situated around $6^{\circ} 42^{\prime} 16^{\prime \prime} \mathrm{N}$ and $126^{\circ} 11^{\prime} 52 " \mathrm{E}$, in altitude ranging from 1160-1350 m. Mosses form thick mats covering roots and tree trunks. Calophyllum blancoi Planch. \& Triana (Clusiaceae), Dacrydium elatum (Roxb.) Wall. (Podocarpaceae), Calamus spp. (Arecaceae) and Pinanga spp. (Arecaceae) species are dominant in the area. Freycinetia sp. (Pandanaceae) are the dominant epiphytic plants, often festooned over large trees. The height of trees ranged from $6-15 \mathrm{~m}$.

The mossy-pygmy forest is situated around $6^{\circ} 43^{\prime} 24^{\prime \prime} \mathrm{N}$ and $126^{\circ} 11^{\prime} 11^{\prime \prime} \mathrm{E}$, ranging in altitude from 1160-1600 m. However, pygmy forest (but not mossy) was also observed as low as
Table 2 Species richness in the different vegetation types in Mt Hamiguitan Range based on sampling plot and transect walk.

\begin{tabular}{lrrrrr}
\hline & \multicolumn{5}{c}{ Vegetation types } \\
\cline { 2 - 6 } Plant groups & $\begin{array}{l}\text { Agro- } \\
\text { ecosystem }\end{array}$ & Dipterocarp & Montane & Mossy & $\begin{array}{l}\text { Mossy- } \\
\text { Pygmy }\end{array}$ \\
\hline Angiosperms & 204 & 326 & 340 & 179 & 272 \\
Gymnosperms & 3 & 12 & 16 & 7 & 13 \\
Ferns & 37 & 71 & 96 & 57 & 50 \\
Fern allies & 2 & 9 & 10 & 3 & 3 \\
Total & 246 & 418 & 462 & 246 & 338 \\
\hline
\end{tabular}

75-275 m in Mati around 6 $43^{\prime} 44^{\prime \prime} \mathrm{N}$ and $126^{\circ} 13^{\prime} 27^{\prime \prime} \mathrm{E}$. The mossy-pygmy forest occupies c. 225 ha. The height of trees ranges from $0.5-2.5 \mathrm{~m}$ and the average diam is $8 \mathrm{~cm}$. The forest is dominated by Leptospermum sp. (Myrtaceae), Weinmannia sp. (Cunoniaceae), Elaeocarpus sp. (Elaeocarpaceae) and Dacrydium sp. (Podocarpaceae). Abundant mosses are present on the forest floor.

\section{Species richness}

Transect walk and sampling plots revealed a total of 878 species, 342 genera and 136 families. Of these, 698 were angiosperms, 25 gymnosperms, 141 ferns and 14 fern allies (Table $1,2)$. This number of species in Mt Hamiguitan is $68 \%$ lower than those observed in Mt Malindang which has 1200 species (Arances et al. 2004), but more species of gymnosperms were observed in Mt Hamiguitan than in Mt Malindang Range.

Among the vegetation types, the montane forest exhibits the highest species richness with 462 species. This is $113 \%$ higher than those observed by Arances et al. (2004) in the montane forest of Mt Malindang Range. The higher species richness in this vegetation type might be due to the intact forest and to the more diverse habitats.

The typical mossy forest with 246 species contains more endemic and rare species. The lower species richness in the dipterocarp forest compared to the montane forest despite the numerous sampling plots (14 plots) may be attributed to the small plot size which is less than the standard set for this type of forest (Fig. 1). It could also be attributed to the exploitation of forest resources as source of livelihood. The presence of tall trees with bigger diam at breast height may also limit the growth of smaller plants.

\section{Species diversity index}

The highest diversity value for trees could be observed in the montane forest with $\mathrm{H}=1.70$, followed by the dipterocarp forest $(H=1.63)$. The mossy-pygmy forest is less diverse, with $\mathrm{H}=1.32$ and the lowest diversity value was observed in the mossy forest with $\mathrm{H}=1.27$.

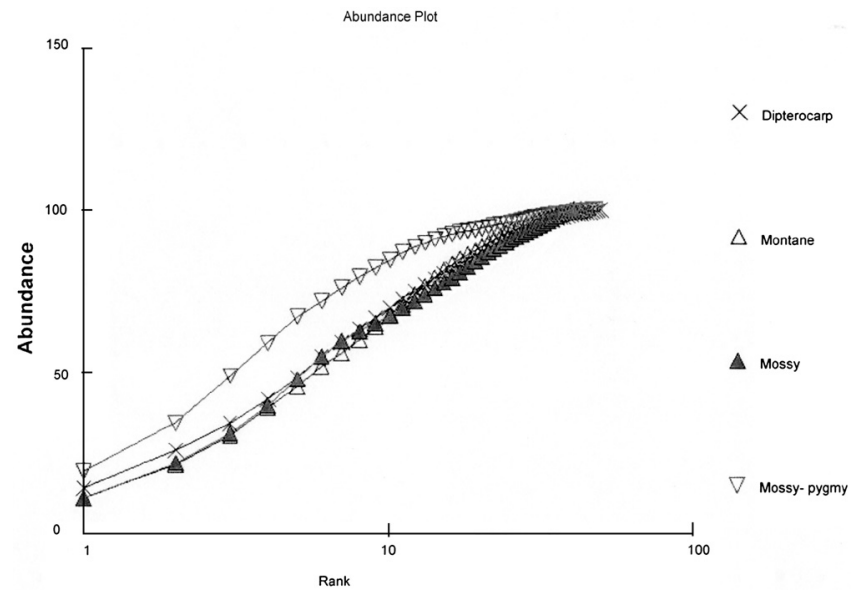

Fig. 1 Species accumulation curve in four vegetation types. 
Table 3 Species composition of trees in the different vegetation types of Mt Hamiguitan Wildlife Sanctuary.

* trees with less than $10 \mathrm{~cm}$ dbh were also counted.

\begin{tabular}{lrrrcc}
\hline Vegetation type & \multicolumn{5}{c}{ Average number of trees } \\
\cline { 2 - 6 } & Species & Individuals & Density & Dominance & Frequency \\
\hline Dipterocarp & 12.71 & 63.71 & 0.14 & 0.027 & 6.06 \\
Montane & 27.17 & 84.17 & 0.21 & 0.041 & 9.278 \\
Typical mossy & 14.50 & 53.57 & 0.13 & 0.035 & 7.38 \\
Mossy - Pygmy* & 24.00 & 1560.50 & 0.39 & 0.26 & 13.61 \\
\hline
\end{tabular}

\section{Species Importance Value (SIV)}

Inventory of trees within the thirty-two $20 \times 20 \mathrm{~m}$ sampling plots revealed a total of 184 species of trees and 1762 individuals with an average of 20 species and 67 individuals. Average numbers per plot are given in Table 3 , and the most important species are listed in Table 4.

In the dipterocarp forest, an average of 64 individuals of trees was observed in all sampling plots. Lithocarpus Ilanosii Rehder has the highest species importance value, followed by Shorea astylosa Foxw. and Zanthoxylum diabolicum Elmer (Rutaceae). These tree species with the highest species importance values differ from those recorded in Mt Malindang where Cyathea brevipes Copel. (Cyatheaceae) ranked first with $79 \%$, followed by Lithocarpus philippinense (A.DC.) Rehder (Arances et al. 2004). Lithocarpus and Shorea are also dominant in the dipterocarp forest of Mt Apo (Heaney \& Regalado 1998).
Table 4 Summary of top five species of trees in the different vegetation types with their species importance value (SIV) and ranks.

\begin{tabular}{llr}
\hline Vegetation types/species of trees & Local name & SIV (\%) \\
\hline Dipterocarp forest & & \\
Lithocarpus Ilanosii (A.DC.) Rehder & Ulayan & 50 \\
Shorea astylosa Foxw. & Yakal & 46 \\
Zanthoxylum diabolicum Elmer & Badbad & 43 \\
Xanthostemon sp. & Magkuno & 40 \\
Calophyllum blancoi Planch. \& Triana & Bitanghol & 33 \\
Montane forest & & \\
Falcatifolium gruezoi de Laub. & & 37 \\
Shorea polysperma (Blanco) Merr. & Tanguile & 30 \\
Agathis philippinensis Warb. & Almaciga & 28 \\
Syzygium sp. & Lumboy-lumboy & 28 \\
Calophyllum blancoi Planch. \& Triana & Bitanghol & 26 \\
Typical mossy forest & & \\
Gordonia subclavata Burkill & & 27 \\
Unidentfied sp. & Tagokan & 17 \\
Agathis philippinensis Warb. & Almaciga & 5 \\
Osmoxylon simplicifolium (Elmer) Philipson & & 5 \\
Aralia sp. & & 5 \\
Mossy - Pygmy forest & & \\
Tristaniopsis micrantha (Merr.) & & 32 \\
$\quad$ Peter G.Wilson \& J.T.Waterh. & & 46 \\
Leptospermum flavescens J.Sm. & Bitanghol & 37 \\
Calophyllum blancoi Planch. \& Triana & & \\
Dacrydium elatum (Roxb.) Wall. & & \\
Falcatifolium gruezoi de Laub. & & \\
\hline & & \\
\hline
\end{tabular}

Table 5 Endemism in the Philippines compared to Mt Hamiguitan Range. Based on specimens identified to species only.

\begin{tabular}{|c|c|c|c|c|c|c|c|c|}
\hline \multirow[t]{3}{*}{ Plant group } & \multicolumn{8}{|c|}{ Total number and percentage of endemic species } \\
\hline & \multicolumn{2}{|c|}{ Philippines } & \multicolumn{2}{|c|}{ Mindanao } & \multicolumn{2}{|c|}{ Malindang } & \multicolumn{2}{|c|}{ Hamiguitan } \\
\hline & Species & Endemism & Species & Endemism & Species & Endemism & Species & Endemism \\
\hline Angiosperms & $8000+$ & 3200 & No data & No data & 450 & $107(24 \%)$ & 365 & $153(42 \%)$ \\
\hline Gymnosperms & 33 & 6 & No data & 3 & 129 & $53(41 \%)$ & 13 & $1(8 \%)$ \\
\hline Fern and Fern allies & 1027 & 351 & 632 & 183 & 246 & $28(11 \%)$ & 99 & $9(9 \%)$ \\
\hline Total & $9060+$ & 3557 & No data & No data & 825 & $188(23 \%)$ & 477 & $163(37 \%)$ \\
\hline
\end{tabular}

The montane forest had the highest average number of species per plot (27) and the highest number of individuals (84). This might be due to the relative absence of human activities and the environmental itself that favours growth of trees. Calophyllum blancoi (Clusiaceae) was observed in all vegetation types. Merrill (1926) reported that $C$. blancoi could be observed in the primary forest at low and medium altitude and is often abundant there. Two species were observed in both dipterocarp and montane forest, namely Schefflera sp. (Araliaceae) and Shorea polysperma (Blanco) Merr. with $29 \%$ and $21 \%$ SIV, respectively. Falcatifolium gruezoi de Laub. (Podocarpaceae) was observed both in the montane and mossy forest with $37 \%$ and $29 \%$ SIV. Only five species over $20 \%$ SIV were observed in Mt Malindang, namely Polyosma philippinensis Merr. (Saxifragaceae), Clethra lancifolia Turcz. (Clethraceae), Cyathea brevipes, Lithocarpus philippinensis and Pometia pinnata J.R.Forst. \& G.Forst. (Sapindaceae).

\section{ASSESSMENT ON THE STATUS OF THE FLORA OF MT HAMIGUITAN RANGE}

The Philippines is the home of 3557 endemic species with 26 endemic genera of vascular plants. Of these, 3200 species are angiosperms, 6 gymnosperms and 351 pteridophytes (ferns and fern allies) (Madulid 1991). In Mt Hamiguitan Range, we were able to identify 477 species to species level. A comparison of endemism is given in Table 5, a breakdown of the status of these species in taxonomic groups is presented in Table 6, and into vegetation types in Table 7. Of the species found in Mt Hamiguitan Range, 163 (37\%) are endemic to the Philippines which is equivalent to $5 \%$ of the total number of endemic plants in the Philippines (Table 5). Thirty-five species (7\%) are threatened, 33 species $(7 \%)$ rare and 204 species (43\%) were assessed as economically important (Table 6). Of the 530 threatened species in the Philippines, 35 (7\%) were found in Mt Hamiguitan (Table 8)' The endemism of vascular plants in Mt Hamiguitan Range is higher compared to the Malindang Range where Arances et al. (2004) found only $23 \%$ endemic species.

Table 6 Threatened, rare and economically important plants in Mt Hamiguitan Range. Based on specimens identified to species only, Fern allies not distinguished in all cases. $\mathrm{N}=$ Number of species; $\mathrm{T}=$ Number of threatened species.

\begin{tabular}{|c|c|c|c|c|c|c|c|c|}
\hline \multirow[t]{3}{*}{ Plant group } & \multirow{2}{*}{\multicolumn{2}{|c|}{ Philippines }} & \multirow{2}{*}{\multicolumn{2}{|c|}{ Malindang }} & \multicolumn{4}{|c|}{ Hamiguitan } \\
\hline & & & & & \multicolumn{3}{|c|}{ Rare } & \multirow{2}{*}{$\frac{\text { Economic }}{\mathrm{N}}$} \\
\hline & $\mathrm{N}$ & $\mathrm{T}$ & $\mathrm{N}$ & $\mathrm{T}$ & $\mathrm{N}$ & $\mathrm{T}$ & $\mathrm{N}$ & \\
\hline Angiosperms & $8000+$ & 440 & 450 & 45 & 365 & 25 & 15 & 161 \\
\hline Gymnosperms & 33 & 5 & 129 & 5 & 13 & 1 & 3 & 9 \\
\hline Ferns & 1027 & 68 & 246 & 4 & 88 & 6 & 13 & 28 \\
\hline Fern allies & & 17 & & & 11 & 3 & 2 & 6 \\
\hline Total & $9060+$ & 530 & 825 & 54 & 477 & 35 & 33 & 204 \\
\hline
\end{tabular}


Table 7 Assessment of the status of species of Phanerogams per vegetation type. Status of threatened species: CES = Critically endangered species; $\mathrm{ES}=$ Endangered species; $\mathrm{V}=$ Vulnerable; OTS = Other threatened species.

Vegetation types

\begin{tabular}{|c|c|c|c|c|c|c|}
\hline \multirow{2}{*}{\multicolumn{2}{|c|}{ Conservation status }} & \multirow[b]{2}{*}{ Agro- } & \\
\hline & & & Dipterocarp & Montane & Mossy & Mossy- \\
\hline \multicolumn{2}{|l|}{ Endemic } & 44 & 78 & 86 & 49 & 66 \\
\hline \multirow[t]{4}{*}{ Threatened } & CES & 2 & 2 & 4 & 1 & 2 \\
\hline & ES & 2 & 4 & 6 & 1 & 2 \\
\hline & V & 9 & 14 & 10 & 8 & 5 \\
\hline & OTS & 2 & 2 & & & \\
\hline \multicolumn{2}{|l|}{ Rare } & 3 & 16 & 23 & 23 & 22 \\
\hline \multicolumn{7}{|c|}{ Economically } \\
\hline \multicolumn{2}{|c|}{ important species } & 98 & 114 & 105 & 65 & 75 \\
\hline
\end{tabular}

Assessment of the endemicity of trees per vegetation type, based on the sampling plots, revealed that the mossy-pygmy forest possesses the highest number of endemic species having a value of $32 \%$ (Table 7). This confirms the results of Arances et al. (2004) in Mt Malindang that as elevation increases there is also an increasing number of endemic plants.

The largest numbers of rare species were observed in the montane to the mossy-pygmy forest with 22-23 species in each type, which is equivalent to $67-70 \%$ of the total rare species in Mt Hamiguitan Range. The smallest number of rare species was observed in the agro-ecosystem (Table 7). Economically important species occur in all vegetation types and are not particularly common in the agro-ecosystem.

Some of the rare and endemic plants observed are Calamus merrillii Becc., C. ornatus var. philippinensis Becc., Nepenthes alata, N. argentii Jebb \& Cheek, N. mira Jebb \& Cheek and $N$. copelandii Merr. The presence of the rare species such as
Gnetum latifolium Blume (Gnetaceae), Schizaea inopinata Selling (Schizaeaceae), S. malaccana Hook., Platycerium coronarium (Konig ex Muell.) Desv. (Polypodiaceae), Psilotum nudum (L.) P.Beauv. (Psilotaceae) and P. complanatum Sw. are noteworthy (Fig. 2). However, there is a need to protect and conserve the habitat of Nepenthes copelandii in the montane, mossy and mossy-pygmy forests in San Isidro since this plant species is critically endangered, endemic and rare (Fig. 3). Mt Hamiguitan mountain range is the habitat of six species of pitcher plants which is $50 \%$ of the total number of Nepenthes in the Philippines. It could also be noted that five species of Shorea were observed in the dipterocarp forest. While Shoreaspecies are common in other Asian countries (Ashton 1992), these dipterocarps are critically endangered, endemic and vulnerable in the Philippines.

Of the four species of Schizaea occurring in the Philippines, three have been found in Mt Hamiguitan Range, viz. Schizaea dichotoma (L.) J.Sm., S. inopinata and S. malaccana. The last two species are of equal botanical importance as these are new records in Mindanao and collected only once or twice in the Philippines (Table 9). Schizaea inopinnata was collected only once in Bohol in 1923 while S. malaccana was recently collected only in Mindoro and Sibuyan in 1993 (Barcelona et al. 1996).

Another important finding is the number of new records for the Philippines and for Mindanao (Table 10). Eight new records of plant species in Mindanao include Elaeocarpus argenteus Merr., E. verticillatus Elmer, Patersonia lowii Stapf (Iridaceae), Astronia lagunensis Merr. (Melastomataceae), Nepenthes argentii, N. mira, Schizaea inopinata and S. malaccana. Nepenthes maxima is a new record for the Philippines, until now being reported from Sulawesi, New Guinea and the Moluccas. Noteworthy is also the discovery of the endemic genus Greeniopsis

Table 8 Endangered, endemic and rare species of plants that must be given high priority for protection and conservation. Status: CES = Critically endangered $\mathrm{ES}=$ Endangered; $\mathrm{V}=$ Vulnerable; OTS = Other threatened species, $\mathrm{E}=$ Endemic; $\mathrm{R}=$ rare. Vegetation types: $\mathrm{A}=\mathrm{Agro}$-ecosystem; $\mathrm{D}=\mathrm{Dipterocarp}$ forest; $\mathrm{M}=$ Montane forest; Mo = Mossy forest; $\mathrm{M}-\mathrm{P}=$ Mossy - Pygmy forest. Location: I = San Isidro; $\mathrm{G}=\mathrm{Gov}$. Generoso; $\mathrm{M}=\mathrm{Mati}$.

\begin{tabular}{|c|c|c|c|c|c|c|}
\hline & Species & Family & Status & Vegetation types & Altitude ( $\mathrm{m}$ asl) & Location \\
\hline 1 & Nepenthes copelandii Merr. & Nepenthaceae & CES, E, R & $\mathrm{M}, \mathrm{Mo}, \mathrm{M}-\mathrm{P}$ & 1180 & I \\
\hline 2 & Paphiopedilum adductum Asher & Orchidaceae & CES, E & $\mathrm{M}, \mathrm{M}-\mathrm{P}$ & 1146 & I \\
\hline 3 & Rhododendron kochii Stein & Ericaceae & CES, E & $\mathrm{D}, \mathrm{M}$ & $540-980$ & 1 \\
\hline 4 & Shorea astylosa Foxw. & Dipterocarpaceae & CES, E & $A, D, M$ & $120-1060$ & I, M, G \\
\hline 5 & Shorea polysperma (Blanco) Merr. & Dipterocarpaceae & CES, E & $\mathrm{D}$ & $320-620$ & $\mathrm{I}, \mathrm{M}, \mathrm{G}$ \\
\hline 6 & Alocasia zebrina C.Koch \& Veitch & Araceae & $E S, E$ & $\mathrm{D}$ & 685 & 1 \\
\hline 7 & Diospyros philippinensis A.DC. & Ebenaceae & $E S, E$ & $A, D$ & $240-820$ & I \\
\hline 8 & Medinilla magnifica Lindl. & Melastomataceae & $E S, E$ & $\mathrm{D}, \mathrm{M}$ & $420-980$ & $\mathrm{I}, \mathrm{M}$ \\
\hline 9 & Nepenthes bellii K.Kondo & Nepenthaceae & ES, S, R & $\mathrm{M}, \mathrm{M}-\mathrm{P}$ & $980-1560$ & 1 \\
\hline 10 & Paphiopedilum ciliolare (Rchb.f.) Stein & Orchidaceae & $E S, E$ & $\mathrm{M}, \mathrm{Mo}, \mathrm{M}-\mathrm{P}$ & $905,965,1220$ & I \\
\hline 11 & Agalmyla persimilis R.Br. & Gesneriaceae & $\mathrm{V}, \mathrm{E}$ & A, D & $380-860$ & $\mathrm{I}, \mathrm{M}$ \\
\hline 12 & Aeschynanthus miniaceous R.Br. & Gesneriaceae & $\mathrm{V}, \mathrm{E}$ & $A, D$ & $380-740$ & 1 \\
\hline 13 & Cinnamomum mercadoi S.Vidal & Lauraceae & $\mathrm{V}, \mathrm{E}$ & M, Mo & $920-1100$ & I \\
\hline 14 & Dendrobium sanderae var. surigaense Quis. & Orhidaceae & $\mathrm{V}, \mathrm{E}$ & $\mathrm{M}, \mathrm{Mo}, \mathrm{M}-\mathrm{P}$ & $920-1200$ & 1 \\
\hline 15 & Shorea contorta S.Vidal & Dipterocarpaceae & $\mathrm{V}, \mathrm{E}$ & $A, D$ & $360-740$ & $\mathrm{I}, \mathrm{M}$ \\
\hline 16 & Shorea guiso (Blanco) Blume & Dipterocarpaceae & $\mathrm{V}, \mathrm{E}$ & $A, D, M$ & $240-820$ & $\mathrm{I}, \mathrm{M}$ \\
\hline 17 & Shorea negrosensis Foxw. & Dipterocarpaceae & $\mathrm{V}, \mathrm{E}$ & $A, D$ & & $\mathrm{I}, \mathrm{M}$ \\
\hline 19 & Myristica philippinensis Lam. & Myristicaceae & OTS, E & $A, M$ & $320-640$ & $\mathrm{I}, \mathrm{M}$ \\
\hline 20 & Calamus merrilii Becc. & Arecaceae & $\mathrm{R}, \mathrm{E}$ & $\mathrm{D}, \mathrm{M}, \mathrm{Mo}$ & $140-1350$ & $\mathrm{I}, \mathrm{M}$ \\
\hline 21 & Calamus ornatus var. philippinensis Becc. & Arecaceae & $\mathrm{R}, \mathrm{E}$ & $\mathrm{D}, \mathrm{M}, \mathrm{Mo}, \mathrm{M}-\mathrm{P}$ & $170-1200$ & I, M, G \\
\hline 22 & Nepenthes argentii Jebb \& Cheek & Nepenthaceae & $R, E$ & $\mathrm{M}, \mathrm{M}-\mathrm{P}$ & $920-1145$ & 1 \\
\hline 23 & Nepenthes mira Jebb \& Cheek & Nepenthaceae & $R, E$ & $\mathrm{D}, \mathrm{M}, \mathrm{M}-\mathrm{P}$ & $870-1200$ & I, M, G \\
\hline 24 & Agathis philippinensis Warb. & Araucariaceae & $\mathrm{E}$ & $\mathrm{D}, \mathrm{M}, \mathrm{Mo}, \mathrm{M}-\mathrm{P}$ & $905-1235$ & $\mathrm{I}, \mathrm{G}, \mathrm{M}$ \\
\hline 25 & Buchanania nitida Engl. & Anacardiaceae & $\mathrm{E}$ & $A, D, M, M o, M-P$ & $140-1200$ & I, M, G \\
\hline 26 & Dillenia philippinensis Rolfe & Dilleniaceae & $\mathrm{E}$ & $A, M$ & $120,1150-1200$ & $\mathrm{I}, \mathrm{M}, \mathrm{G}$ \\
\hline 27 & Medinilla cumingii Vand. & Melastomataceae & $\mathrm{E}$ & D & $540-820$ & 1 \\
\hline 28 & Medinilla malindangensis Merr. & Melastomataceae & $\mathrm{E}$ & $\mathrm{D}$ & 380 & $\mathrm{M}$ \\
\hline 29 & Gnetum latifolium Blume & Gnetaceae & $\mathrm{R}$ & $\mathrm{M}, \mathrm{M}-\mathrm{P}$ & $920-1145$ & $\mathrm{I}, \mathrm{M}$ \\
\hline 30 & Nepenthes maxima Reinw. ex Nees & Nepenthaceae & $\mathrm{R}$ & M, Mo, M-P & 1165 & 1 \\
\hline 31 & Psilotum nudum (L.) P.Beauv. & Psilotaceae & $\mathrm{R}$ & $\mathrm{D}, \mathrm{M}, \mathrm{Mo}, \mathrm{M}-\mathrm{P}$ & $905-1200$ & 1 \\
\hline 32 & Schizaea inopinata Selling & Schizaeaceae & $\mathrm{R}$ & $\mathrm{D}, \mathrm{M}$ & 280 & G \\
\hline 33 & Schizaea malaccana Hook. & Schizaeaceae & Rare & $\mathrm{D}$ & 1095 & 1 \\
\hline
\end{tabular}




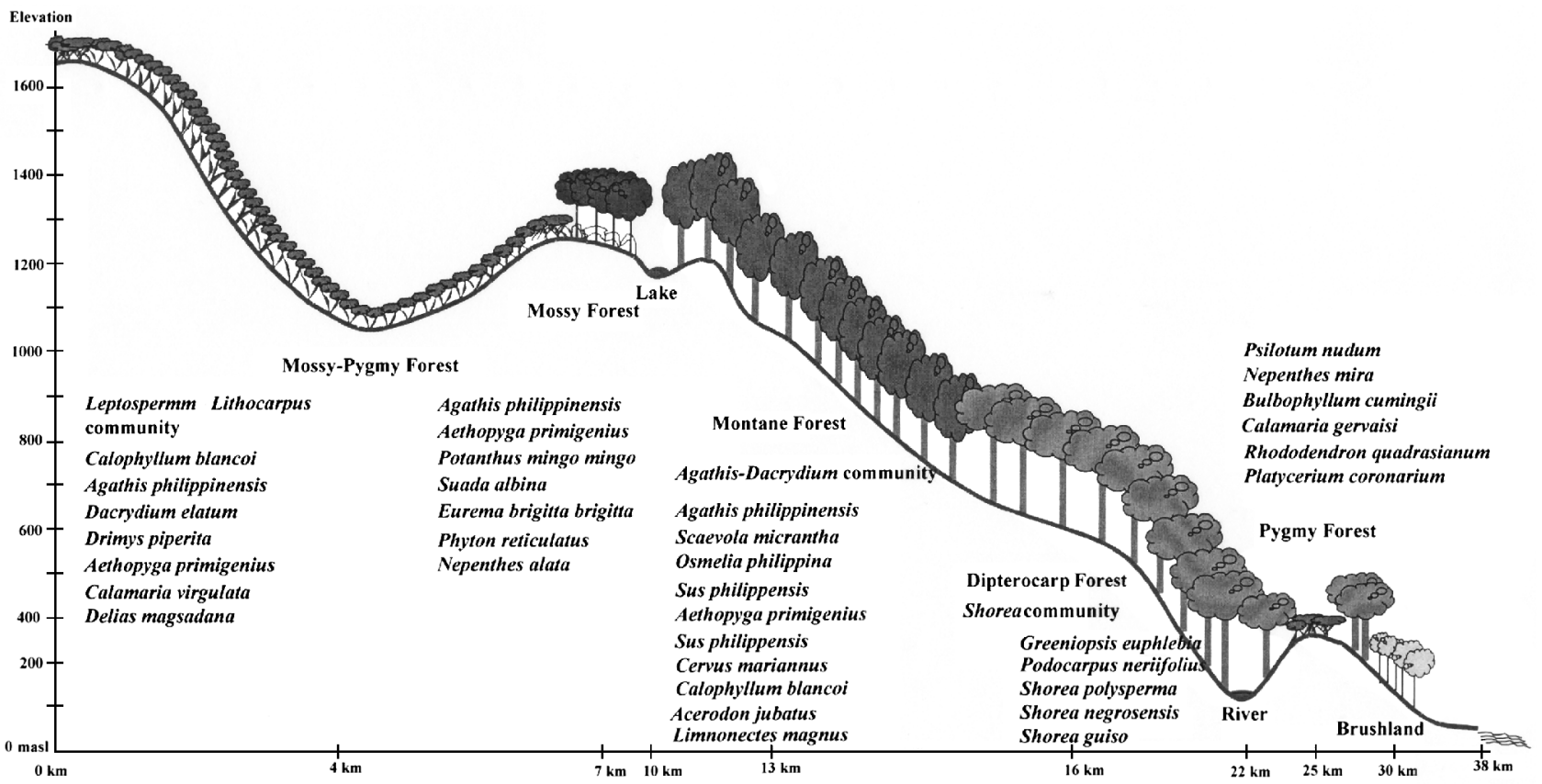

Fig. 2 Transect diagram of Mt Hamiguitan showing the altitudinal distribution of vegetation types, threatened, rare, endemic and economically important species from Hamiguitan Peak to Sitio Magum, Mati.

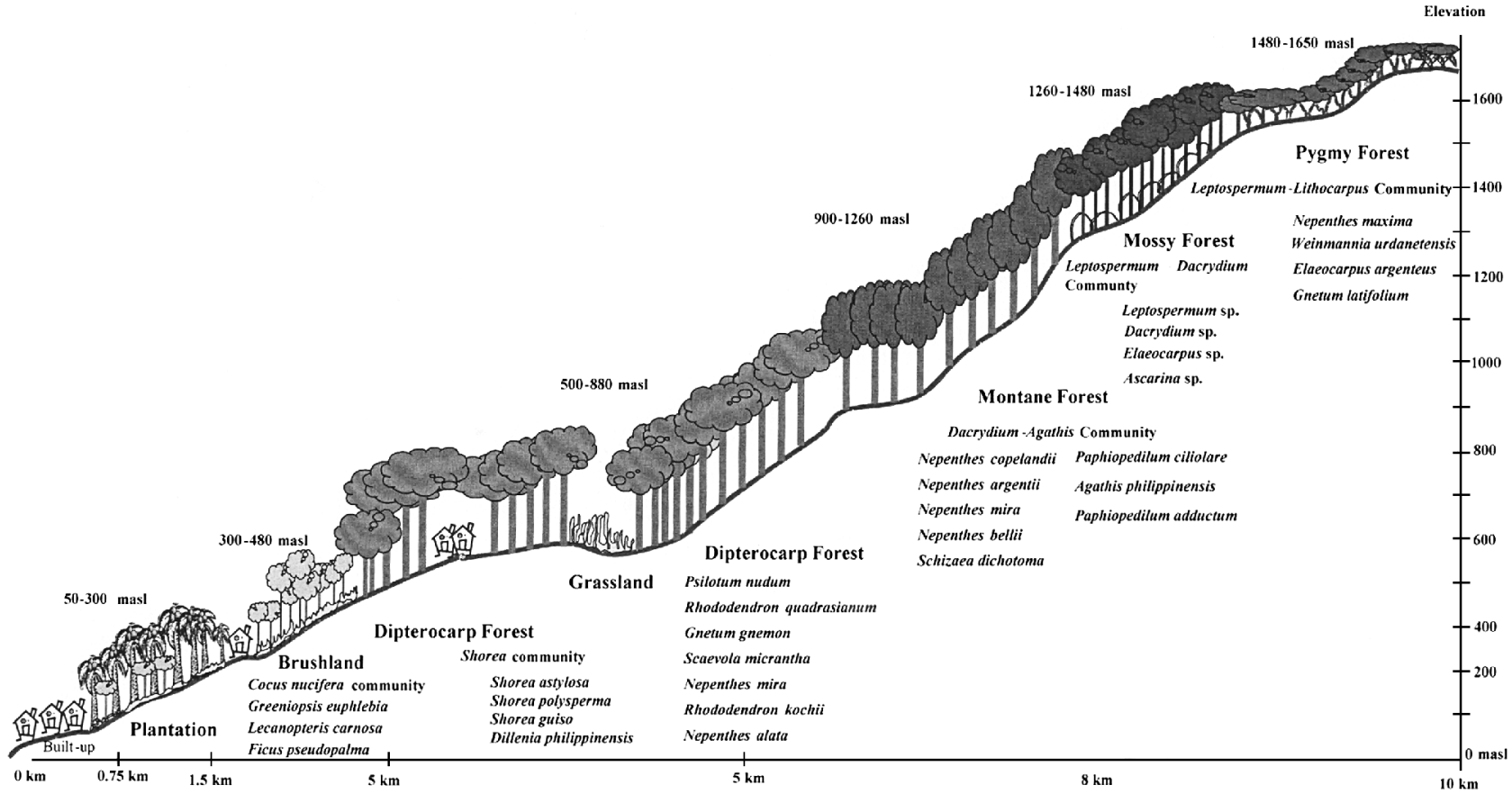

Fig. 3 Transect diagram of Mt. Hamiguitan showing the altitudinal distribution of vegetation types, threatened, rare, endemic and economically important species from Sitio Tumalite to Hamiguitan Peak.

(Rubiaceae). Of the six Philippine species of Greeniopsis, two species, Greeniopsis euphlebia Merr. and G. megalantha Merr. were found to be common in the area, from agro-ecosystem to mossy forest.

\section{CONCLUSIONS}

Mt Hamiguitan Range is the habitat of one new record in the Philippines and 8 new records for Mindanao and harbours some endemic, threatened, rare and economically important species of plants needing high priority for protection and conservation.
Density of threatened species is highest in the dipterocarp forest and decreases at higher elevation. Species richness was highest in the montane forest and lowest in typical mossy forest. Endemism increases from the dipterocarp to the montane forest but is lower in the mossy forest.

Table 9 Total number and percentage of endemic species of trees, averages of 6 sampling plots per vegetation type.

\begin{tabular}{lcrl}
\hline Vegetation type & Species & Endemic species \\
\hline Dipterocarp forest & 49 & 7 & $(14.29 \%)$ \\
Montane forest & 42 & 7 & $(16.67 \%)$ \\
Mossy forest & 46 & 11 & $(23.91 \%)$ \\
Mossy - Pygmy forest & 47 & $15 \quad(31.91 \%)$ \\
\hline
\end{tabular}


Table 10 New records of plants in the Philippines and in Mt Hamiguitan. * = earlier reported in Sulawesi, New Guinea and Moluccas; ${ }^{* *}=2$ nd collection since 1923

\begin{tabular}{|c|c|c|c|}
\hline \multirow{2}{*}{\multicolumn{2}{|c|}{ Family/species }} & \multicolumn{2}{|c|}{ New record } \\
\hline & & Philippines & Mindanao \\
\hline \multicolumn{4}{|c|}{ I Elaeocarpaceae } \\
\hline & 1 Elaeocarpus argenteus Merr. & & l \\
\hline & 2 Elaeocarpus verticillatus Elmer & & l \\
\hline \multicolumn{4}{|c|}{ II Iridaceae } \\
\hline & 3 Patersonia lowii Stapf. & & I \\
\hline \multicolumn{4}{|c|}{ III Melastomataceae } \\
\hline & 4 Astronia lagunensis Merr. & & I \\
\hline \multicolumn{4}{|c|}{ IV Nepenthaceae } \\
\hline & 5 Nepenthes argentii Jebb \& Cheek & & l \\
\hline & Nepenthes maxima Reinw. ex Nees & $I^{*}$ & \\
\hline & 7 Nepenthes mira Jebb \& Cheek & & I \\
\hline \multicolumn{4}{|c|}{ V Schizaeaceae } \\
\hline & 8 Schizaea inopinata Selling & & $I^{* *}$ \\
\hline & 9 Schizaea malaccana Hook. & & 1 \\
\hline Tot & & 1 & 8 \\
\hline
\end{tabular}

Acknowledgements Our sincere thanks and gratitude to the Commission on Higher Education (CHED) for funding this research, Central Mindanao University (CMU), Davao Oriental State College of Science and Technology (DOSCST), Leonard L. Co, Mayor Apolinar Q. Ruelo, Barangay Officials, 'Bantay Gubat' of the Municipalities of San Isidro, Mati and Governor Generoso for their assistance and support and to PAWD, DENR XI for the Gratuitous Permit.

\section{REFERENCES}

Amoroso VB, Acma FM, Pava H. 1996. Diversity status and ecology of Pteridophytes in three forests in Mindanao. In: Canus JM, Johns RJ (eds), Pteridology in perspective: 53-60. Royal Botanical Garden, Kew.

Arances JB, Amoroso VB, Gruezo WS, Ridsdale CE, Visser L, Tan BC, Rufila LV, Galvezo JB, Opiso GS, Comilap R, Pacut N, Montimar B, Sacul S. 2004. Development of a participatory methodology for inventory and assessment of floral resources and their characterization in the Montane Forest of Mt Malindang. SEAMEO SEARCA. College Laguna. PDM Press, Quezon City, Philippines.
Ashton PS. 1982. Dipterocarpaceae. Flora Malesiana, Ser. I, Vol. 9: 237552.

Barcelona JF, Hernandez BF, Price MG. 1996. Philippine Schizaea. Asia Life Sciences.

Berg CC, Corner EJH. 2005. Moraceae (Ficus). Flora Malesiana, Ser. I, Vol. 17 / 2.

Brower JE, Zar JH. 1977. Field and laboratory methods for general ecology. Wm. C. Brown, Dubuque, lowa.

Brummitt RK. 1992. Vascular plant families and genera. Royal Botanic Gardens, Kew.

Cootes J. 2001. The orchids of the Philippines. Times Editions, Singapore. De Wilde WJJO. 2000. Myristicaceae. Flora Malesiana, Ser. I, Vol. 14.

DENR Administrative Order No. 2007-01. Establishing the national list of threatened Philippine plants and their categories, and the list of other wildlife species. Department of Environment and Natural Resources, Visayas Avenue, Diliman, Quezon City.

Heaney LR, Regalado Jr JC. 1998. Vanishing treasure of the Philippine rainforest. The Field Museum, Chicago, Illinois.

Hovenkamp PH et al. 1998. Polypodiaceae. Flora Malesiana, Ser. II, Vol. 3: 1-234.

Huang TC (ed). 1996. Flora of Taiwan. 2nd ed., Vol. 2. Angiospermae. Editorial Committee of the Flora of Taiwan, Taipei, Taiwan.

Huang TC. 1997. Daphniphyllaceae. Flora Malesiana. Ser. I, Vol. 13: 145168.

Jebb M, Cheek M. 2001. Nepenthaceae. Flora Malesiana, Ser. I, Vol. 15: 1-157.

Madulid DA. 1991. The endemic genera of flowering plants in the Philippines. Acta Manillana 39: 47-58.

Madulid DA. 1995. A pictorial cyclopedia of Philippine ornamental plants. Bookmark, Inc.

Merrill ED. 1923-1926. An enumeration of Philippine flowering plants. Volumes I-IV. Bureau of Printing, Manila.

Middleton DJ. 2007. Apocynaceae (subfamilies Rauvolfioideae \& Apocynaceae). Flora Malesiana, Ser. I, Vol. 18.

Nooteboom HP. 1998. Davalliaceae. Flora Malesiana, Ser. II, Vol. 3: 235276.

Rödl-Linder G. 1987. Monograph of the fern genus Goniophlebium (Polypodiaceae). Blumea 34: 283-328.

Rojo JP. 1999. Revised lexicon of Philippine trees. Forest Products Research and Development Institute, Department of Science and Technology. College, Laguna 4031, Philippines.

Tan BC, Fernando ES, Rojo JP. 1996. An updated list of endangered Philippine plants. Yushania 3, 2: 1-5.

Zamora PM, Co L. 1986. Guide to Philippine flora and fauna, Vol. IV. Goodwill, Quezon City. 